\title{
A atuação médica nas Forças Armadas
}

\author{
Gustavo Alex Condi
}

\begin{abstract}
De fato, a atuação como médico nas Forças Armadas traz experiências enriquecedoras. Tentarei aqui, brevemente, comentar o período que passei no Exército Brasileiro ao longo do ano de 2006. Inicialmente, é necessário informar que, a cada ano, o Exército, a Marinha e a Aeronáutica visitam algumas escolas médicas a fim de promover palestras de esclarecimento aos sextanistas sobre o papel dos médicos, as nuances entre as Forças, bem como direitos e obrigações.
\end{abstract}

Vale ressaltar que as escolas escolhidas para fornecer os médicos em determinados ano serão preteridas no ano seguinte, propiciando, desta maneira, uma espécie de rodízio. Pois bem. A primeira informação relevante diz respeito à obrigatoriedade dos médicos a se alistarem, enquanto as médicas o fazem em caráter voluntário.

Os militares sabem que as visitas às escolas médicas causam certo desconforto aos doutorandos, pois exercer a atividade médica dentro de unidades militares implica, geralmente, alterar todo um planejamento de vida longamente traçado e ansiosamente aguardado por parte dos recém-formados, nem sempre compreensivelmente dispostos a tal.

No entanto, a atenção às palestras é maior quando começam a ser explanados os rendimentos auferidos durante a permanência nas Forças Armadas. Com pequenas variações entre elas, os auxílios financeiros são basicamente os mesmos.

Por exemplo, recebemos um auxíliodeslocamento, um coeficiente multiplicado pela quilometragem entre o ponto de partida (nosso local de moradia) e o destino. Assim, em valores aproximados, um deslocamento de São Paulo até unidades no Amazonas pode proporcionar $R \$ 20000,00$. O mesmo valor é oferecido quando do retorno ao ponto de origem. Trata-se de um bom começo para o início da carreira. Além disso, existe o auxílio-fardamento equivalente a um soldo para a aquisição dos uniformes. Todos iniciam como Aspirantes a Oficial e, após seis meses, são promovidos a $2^{\circ}$ Tenentes Médicos Temporários, ocasião em que ocorre aumento de salário.

Próximo às formaturas, os alunos das escolas médicas passam por exames classificatórios. Os primeiros colocados tem a oportunidade de escolher os locais mais próximos de suas residências a fim de visitarem seus familiares com maior frequência ou aqueles que pensam nas verbas optam por locais mais distantes. Contudo, não poderão se ausentar de suas unidades tão frequentemente.

Após essa primeira escolha de vagas, caso não haja o total preenchimento delas, haverá ainda uma seleção com menos opções, sendo os doutores enviados a lugares disponíveis nem sempre de sua preferência. Por que ocorre anualmente esta seleção? Porque o quadro fixo dos oficiais de saúde não é capaz de preencher as vagas distribuídas pelo país. Tal se aplica aos farmacêuticos, dentistas e médicos veterinários.

Portanto, a atividade médica nestes locais pode ser alternativa bastante interessante aos colegas aprovados na residência médica e dispostos a "montar uma poupança", uma vez que terão sua vaga na especialidade escolhida garantida por lei no 
ano seguinte. Também é possível servir nas Forças Armadas sem termos sido aprovados na residência, mas fica o lembrete do afinco nos estudos para a futura aprovação nos exames. Foi como aconteceu comigo. Servi como voluntário e não havia passado nos exames. Aproveitava o tempo livre para os estudos.

Então, comentadas até aqui as vias de ingresso, partiremos para o desempenho das funções dentro das instituições. No tocante ao Serviço, podemos ser destacados para as Armas da Infantaria, Artilharia ou Cavalaria. Servi em um BIL, Batalhão de Infantaria Leve, em São Vicente, São Paulo. Lá existe um posto médico comandado por um oficial de carreira, responsável pela equipe de médicos, enfermeiros, dentistas e farmacêuticos. Iniciamos as atividades como temporários, podendo permanecer até sete anos. Quem desejar seguir carreira no Exército e na Marinha, necessita passar pela Escola de Saúde no Rio de Janeiro, e na Aeronáutica, por Belo Horizonte.

Todos os aspirantes passam por um período de adaptação de oito semanas, em que são aprendidos diversos conceitos, desde como marchar corretamente (parece simples, mas não é!), reportarse a um superior até o manuseio dos armamentos como pistolas e fuzis. As atividades do médico dependerão da instituição para a qual for deslocado, ou seja, dentro de um hospital, desempenharemos as funções semelhantes às aprendidas no internato; em batalhões de selva, atenderemos populações ribeirinhas e isoladas do contato urbano.

O batalhão no qual atuei era considerado operacional, ou seja, preparava equipes para atuação em missões de campo e para situações de conflito urbano. Eram realizadas simulações de conduta em casos de conflito urbano e de recuperação de espaços privados como, por exemplo, de indústrias em poder de sequestradores. Todas às vezes que o batalhão passava por algum exercício nas matas do litoral, acompanhávamos o comboio e nos reportávamos ao coronel. O posto médico era responsável pelo atendimento de saúde de um contingente de mais de quinhentas pessoas, além de seus familiares e dos militares da reserva, tanto em caráter ambulatorial como urgencial.

O primeiro óbito que presenciei depois de formado deu-se durante o retorno de um dos campos no Guarujá. A tropa voltava somente após completar uma marcha de dezesseis quilômetros em uma rodovia. Estávamos atrás numa ambulância acompanhando o comboio. Um motociclista colidiu com sua traseira. Assustados, paramos. Era um politraumatizado grave, com rápido rebaixamento de nível de consciência e portador de múltiplas fraturas. As manobras preconizadas pelo ATLS resultaram infrutíferas. Esta foi a experiência que mais me marcou e que contribuiu para a decisão de atuar como cirurgião e lidar com pacientes politraumatizados. 